\title{
LONG-TERM DYNAMICS OF TROPHIC STATE INDICATORS IN PHYTOPLANKTON OF THE COOLING RESERVOIR OF A NUCLEAR POWER PLANT
}

\author{
Tatiana NOVOSELOVA * \\ Sophia BARINOVA ** and Alexander PROTASOV* \\ * Institute of Hydrobiology of National Academy of Science of Ukraine, 12 Geroev Stalingrada Avenue, \\ Kyiv, Ukraine, UA-04210, labtech-hb@ukr.net, pr1717@ukr.net, ORCID: 0000-0002-0204-2007. \\ ** Institute of Evolution, University of Haifa, Mount Carmel, Abba Khoushi Avenue, 199, Haifa, Israel, \\ IL-3498838,sophia@evo.haifa.ac.il, ORCID: 0000-0001-9915-2503.
}

DOI: 10.2478/trser-2021-0001

KEYWORDS: nuclear power plant, cooling reservoir, thermal pollution, phytoplankton, bioindicators, trophic state, Ukraine.

\section{ABSTRACT}

The dynamics of long-term indicators of trophicity in the cooling pond of a nuclear power plant in Ukraine was analyzed by phytoplankton biomass and bioindicators of trophicity. Greater species richness correlated with the number of species-indicators of greater trophicity. During the contourization processes caused by the introduction of filter-feeding mollusks and changes in the operating mode of the nuclear power plant, there was a decrease in the abundance of phytoplankton and trophic state. During decontourization, there was a sequential "return" of previously eliminated taxa and the restoration of the number of indicator species.

ZUSAMMENFASSUNG: Langzeitdynamik trophischer Zustandsindikatoren im Phytoplankton des Kühlreservoirs eines Kernkraftwerks.

Die Dynamik von Langzeitindikatoren für die Trophäe im Kühlteich eines Kernkraftwerks in der Ukraine wurde mit Phytoplankton-Biomasse und Bioindikatoren für die Trophäe analysiert. Ein größerer Artenreichtum korrelierte mit der Anzahl der Artenindikatoren für eine größere Trophäe. Während der Konturierungsprozesse, die durch die Einführung von Mollusken mit Filterfütterung und Änderungen der Betriebsart des Kernkraftwerks verursacht wurden, nahm die Häufigkeit von Phytoplankton und der trophische Zustand ab. Während der Dekontourisierung gab es eine sequentielle "Rückgabe" zuvor eliminierter Taxa und die Wiederherstellung der Anzahl der Indikatorarten.

REZUMAT: Dinamica pe termen lung a indicatorilor stării trofice în fitoplanctonul rezervorului de răcire al unei centrale nucleare.

Dinamica indicatorilor de troficitate pe termen lung în iazul de răcire al unei centrale nucleare din Ucraina a fost analizată prin biomasa fitoplanctonică și bioindicatorii troficităţii. O bogăție mai mare de specii este corelată cu numărul de specii-indicatoare de troficitate mai mare. În timpul proceselor de contorizare cauzate de introducerea moluştelor care alimentează filtrul și modificările modului de funcţionare al centralei nucleare, a existat o scădere a abundenței fitoplanctonului și a stării trofice. În timpul decontorizării, a existat o „revenire” secvențială a taxonilor eliminați anterior și restabilirea numărului de specii indicatoare. 


\section{INTRODUCTION}

The structure and processes of functioning of aquatic ecosystems are highly dynamic and change over time. In reservoirs of techno-ecosystems, the main triggers of changes are the features of the operation of technical objects, including emergency situations that can arise both exogenously and endogenously relative to the techno-ecosystem. For example, exogenous changes can be caused by invasion of alien species, which cause serious restructuring of the entire ecosystem of the reservoir (Karatayev et al., 1997; Zdanowski and Protasov, 1998; Cuhel and Aguilar, 2013; Beshkova et al., 2014, 2017). Cooling reservoirs (WO) of thermal and nuclear power plants are technologically heavily loaded water bodies. Their sanitary condition, water quality, which determines the cleanliness of the surface of heat exchange equipment, significantly depends on the level of development of aquatic organisms, in particular phytoplankton (Novoselova and Protasov, 2015). Phytoplankton characteristics, in turn, can act as an indicator of changes in the state of the entire ecosystem (Barinova et al., 2006, 2019; Protasov et al., 2017).

The aim of our work was to show the reaction of phytoplankton to changes in the trophic status of the cooling pond (CP) of the Khmelnitsky NPP (KhNPP) in a long-term aspect based on bioindication, in particular, based on the dynamics of trophicity indicators.

\section{MATERIAL AND METHODS}

\section{Description of study site}

The KhNPP site is located in the northwestern part of Ukraine (Fig. 1a, b). Cooling of the circulating waters of the two power units is provided by a cooling pond with an area of about $20 \mathrm{~km}^{2}$ and a volume of 120 million $\mathrm{m}^{3}$. Detailed characteristics are presented in (Protasov et al., 2011). The technogenic load experienced by the CP KhNPP in comparison with other cooling ponds of TPPs and NPPs of the temperate climate zone corresponds to the average level (Novoselova and Protasov, 2015, 2016). The paper presents the results of studies of CP KhNPP for 1998-2019. The studies were carried out in summer and early autumn when phytoplankton was most developed.

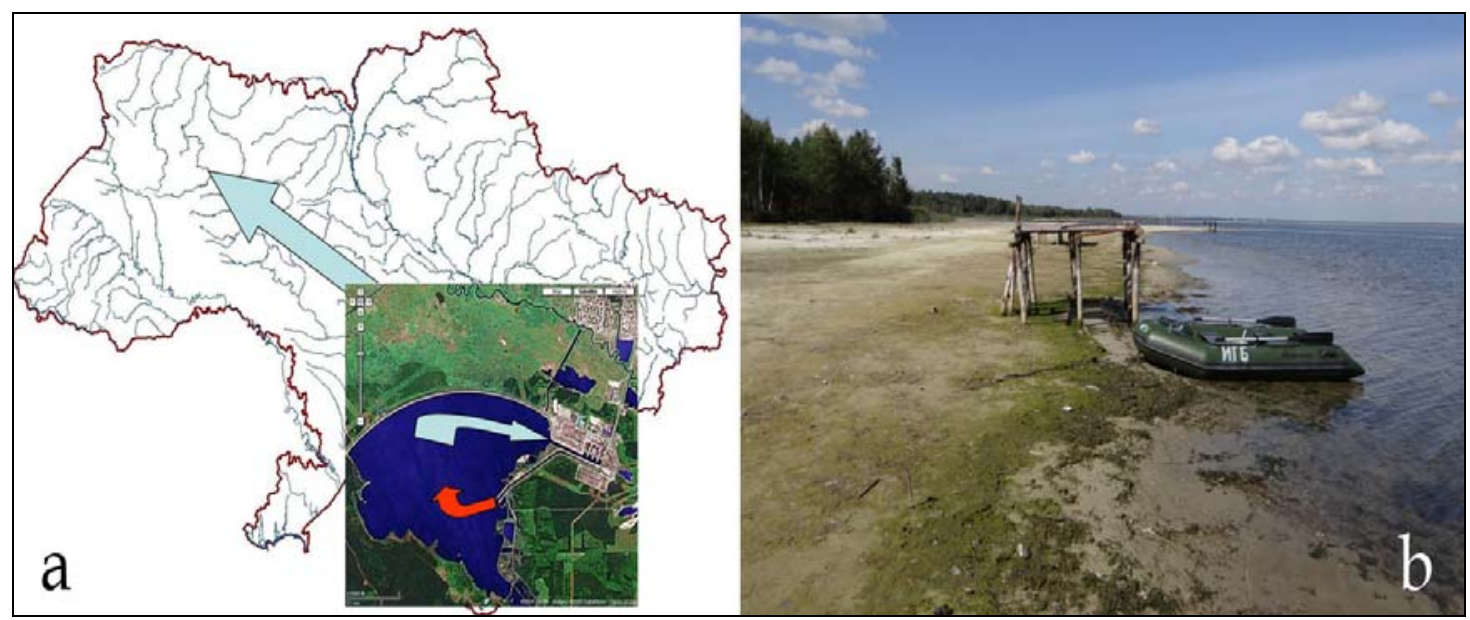

Figure 1: Map of studied reservoir on the territory of Ukraine,

a. blue arrow marked water input, red arrow is hot water outlet to inlet channel of nuclear power plant, b. view of drained part of the coast of the reservoir. 


\section{Sampling and laboratory study}

We have analyzed the parameters of phytoplankton since the start of regular monitoring in the reservoir. The study was conducted during three periods. In 1998-2001 (hereafter referred to as the first period, I), only one unit of the NPP was operating. Since 2004, the second power unit started operation, while the cooling pond was infested by the zebra mussel Dreissena polymorpha (Pallas), most probably in the two years before (20022003) (Protasov et al., 2011). In the second period (II), the studies were carried out in 20052008. In the third period (III), the studies were conducted from 2010 to 2015. A second species of the family Dreissenidae, the quagga mussel Dreissena bugensis (Andrusov, 1897), was recorded for the first time in the cooling pond in 2012 (Fig. 2).
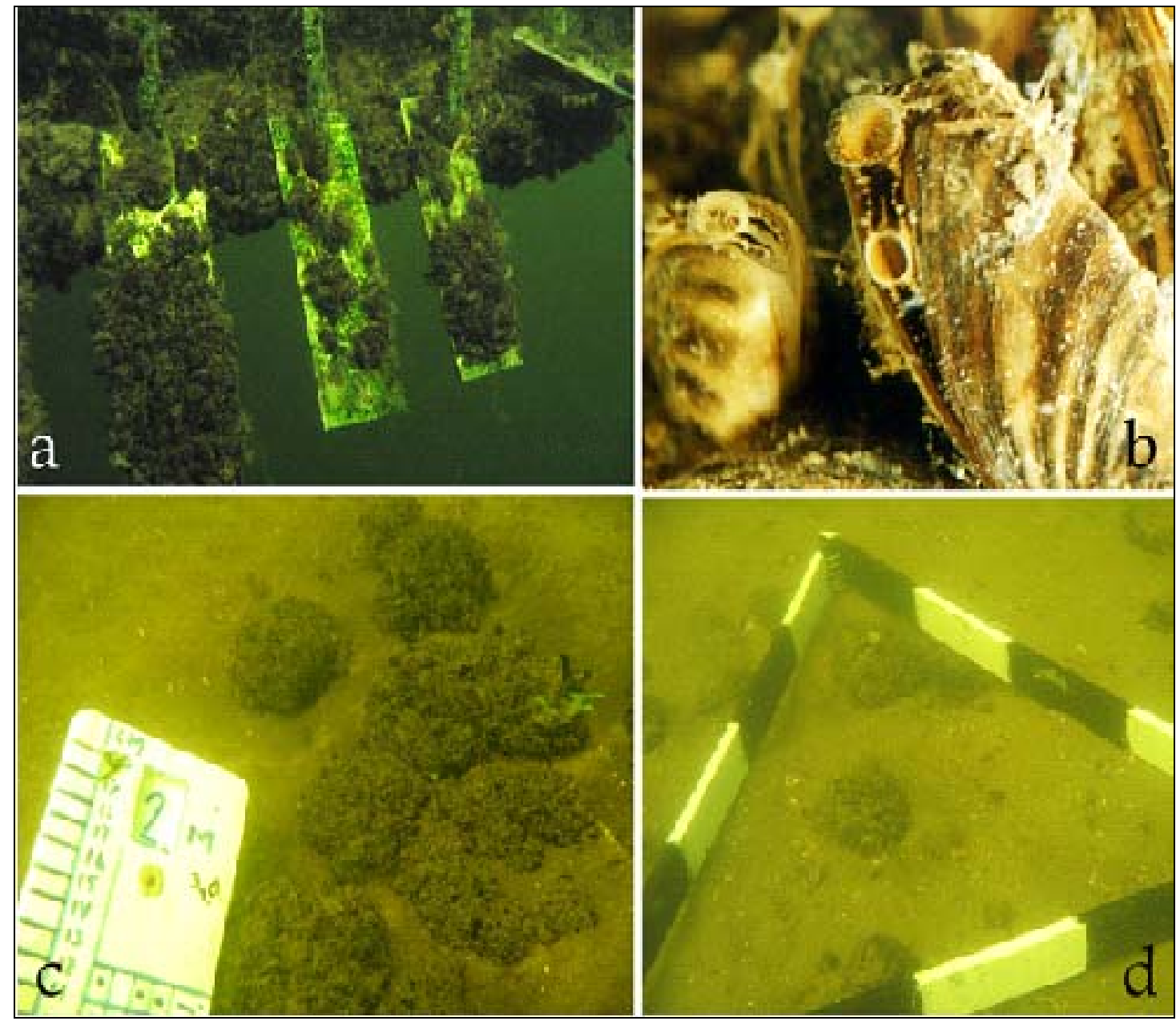

Figure 2: Experimental substrates of algae and zebra mussel fouling and different bottom substrates in cooling reservoir on the territory of Ukraine:

experimental substrata in the NPP inlet channel with zebra mussel fouling (a);

Dreissena polymorpha fouling (b);

bottom site on two m depth with zebra mussel drizes (c);

experimental square for the mollusk's druses measurements, black part is $10 \mathrm{~cm}(\mathrm{~d})$. 
The complex hydrobiological studies were carried out according to standard methods (Arsan et al., 2006; Protasov et al., 2011). The transparency was measured using a Secchi white disk with a diameter of $30 \mathrm{~cm}$. The phytoplankton samples were taken in the pelagic part of the cooling pond over the entire water area, from the surface horizon, using a Patalas bathometer.

The hydrochemical data was received from the Ecological-chemical Laboratory of the Khmelnitsky NPP. The term "the lowest determined taxon" (LDT), which denotes taxa of both species and higher rank defined in accordance with the identification capabilities, was used after Bakanov (1997) to describe the taxonomic richness and diversity of algae. The names and systematic affiliation of phytoplankton taxa were according to the Algaebase database (Guiry and Guiry, 2019). More than $92 \%$ of taxa have been identified to species level. The phytoplankton determination of species-indicators of trophic conditions, followed the recommendations of Barinova et al. $(2006,2019)$. The trophic level was determined by indicators of the abundance of phytoplankton (Oksiyuk et al., 1994). The diversity of algae communities was calculated by the Shannon function, log base was 2 (Arsan et al., 2006); use richness of indicator groups.

\section{RESULTS AND DISCUSSION}

\section{Physical and chemical variables}

The average water transparency over the cooling pond in the summer months during the first study period varied from $1.03 \pm 0.03 \mathrm{~m}$ in June 1998 to $1.33 \pm 0.17 \mathrm{~m}$ in July 1999 . After introducing D. polymorpha (II), the transparency index changed significantly (Fig. 3). The highest average values, $3.02 \pm 0.23 \mathrm{~m}$, within the water body was detected in September 2008 in the inflow canal, where the colonies of D. polymorpha were found at all surfaces of the covering concrete in the temporary absence of flowage (both units did not operate during the study period because of preventive maintenance) (Fig. 1). In some points here, transparency reached four $m$.

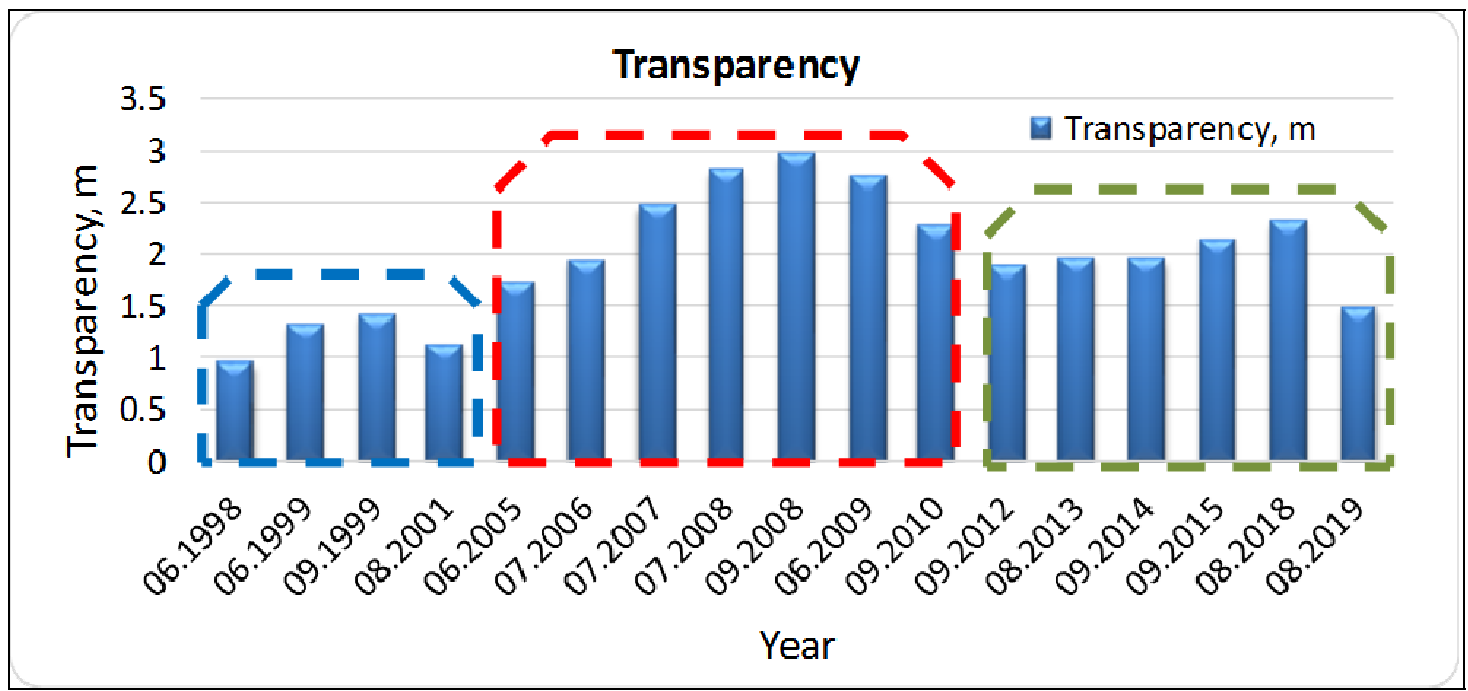

Figure 3: Changes of water transparency in the Khmelnitsky NPP cooling pond in period of investigations (1998-2019).

The dashed lines indicate three periods. 
In the period I, the average annual content of calcium ions $\left(\mathrm{Ca}^{2+}\right)$ varied from 49.71 to $54.85 \mathrm{mg} / \mathrm{dm}^{3}$, while the concentration of sulphate ions $\left(\mathrm{SO}_{4}{ }^{2-}\right)$ was between 41.25 and 95.67 $\mathrm{mg} / \mathrm{dm}^{3}$. The sum of ions in the cooling pond averaged $352.58 \mathrm{mg} / \mathrm{dm}^{3}$, which is a relatively low indicator of mineralization.

Period II of the studies was characterized by a gradual increase in the content of bicarbonate ions and chlorine ions and, in general, total mineralization up to $438.7 \mathrm{mg} / \mathrm{dm}^{3}$. During this period, the trend of decreasing in the concentration of calcium ions continued (the average values in 2006-2010 were $44.86 \mathrm{mg} / \mathrm{dm}^{3}$, reaching $38.0 \mathrm{mg} / \mathrm{dm}^{3}$ in August-September 2006), along with an increase in the sulphate ions content and the concentration of phosphate ions.

In this period, the average content of phosphate ions in the water of the cooling pond increased more than twice, from 0.028 to $0.066 \mathrm{mg} \mathrm{P} / \mathrm{dm}^{3}$. The balance between nitrogen and phosphorus changed, being 9:1 in the first period and 5:1 in the second.

In period III, the transparency decreased to about $1.5-2.0 \mathrm{~m}$. The concentration of calcium ions in water increased to $52.85 \mathrm{mg} / \mathrm{dm}^{3}$ in 2014 and $55.85 \mathrm{mg} / \mathrm{dm}^{3}$ in 2015 (average annual values). In those years, the content of sulphate ions was, on average, 90.36 and 100.95 $\mathrm{mg} / \mathrm{dm}^{3}$, respectively. The indicators of mineralization continued to increase to $566.80 \mathrm{mg} / \mathrm{dm}^{3}$ on average in 2015. The entire studied period (since 1998) was marked by an increase in the content of phosphate ions. In period III, their average annual concentration reached $0.228 \mathrm{mg}$ $\mathrm{P} / \mathrm{dm}^{3}$ in 2014 and $0.263 \mathrm{mg} \mathrm{P} / \mathrm{dm}^{3}$ in 2015 . The balance between nitrogen and phosphorus decreased to $2: 1$ in this period.

\section{Phytoplankton species richness}

During the study period, 383 taxa of algae and cyanobacteria from eight divisions were found in phytoplankton of the pelagic part of the $\mathrm{CP}$ and channels. The main part of algae (352 species and infraspecies) was identified to a species or lower systematic level. The most widely represented was Chlorophyta (144 taxa) and Bacillariophyta (109), Cyanobacteria numbered 54, Euglenophyta 20, Streptophyta (Charophyta) 18, Chrysophyta and Xanthophyta 17, Miozoa (Dinophyta) eight, and Cryptophyta three. Distribution is represented in figure 4, where the Standard Deviation line cut off most of the richest divisions - diatoms, green algae, and cyanobacteria.

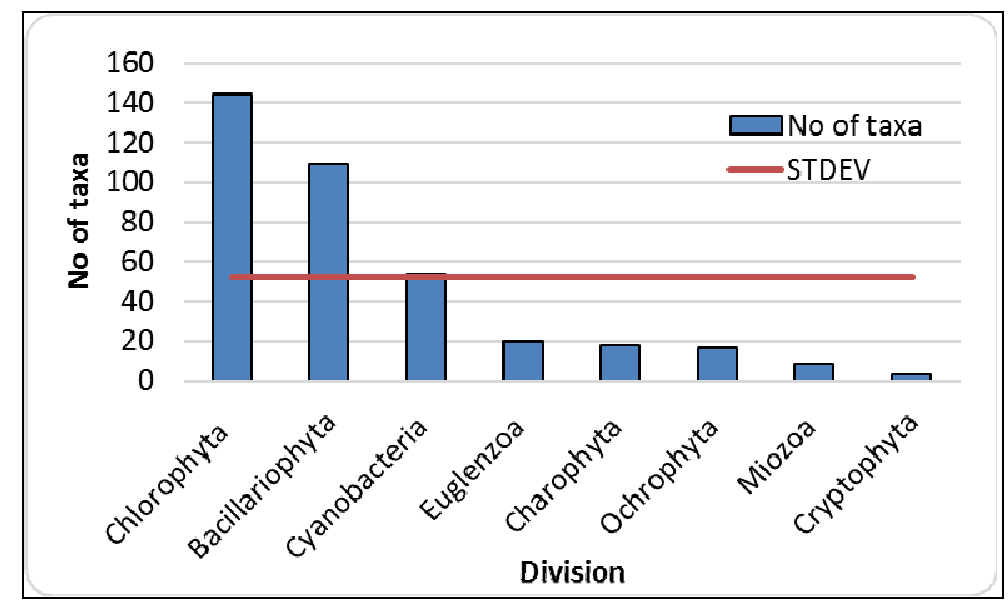

Figure 4: Distribution of revealed taxa of algae and cyanobacteria over taxonomic division in phytoplankton of the Khmelnitsky NPP cooling pond in period of investigations (1998-2019). 


\section{Algae-indicators of trophic state}

Algae-indicators of trophicity made up $34 \%$ of the total phytoplankton composition and were found throughout the observation period. The list of indicators was formed by representatives of three divisions, in which charophytes replaced green algae in comparison to figure 4. Among them, diatoms numbered 83 species-indicators, cyanobacteria 27, and charophyte 11. The most represented were indicators of meso-eutrophic (me) conditions (38 taxa), oligo-mesotrophic (o-m) there were 24, eutrophic (e) 20, mesotrophic (m) 16, oligotrophic (ot) and oligo-eutrophic (o-e) 10, hypertrophic (he) three taxa. Thus, there were 72 broadly specialized, 49 highly specialized. The share of indicators in the list of species was $50.1 \%$ in cyanobacteria, $60.9 \%$ in charophytes, and $69.7 \%$ in diatoms (Fig. 5).

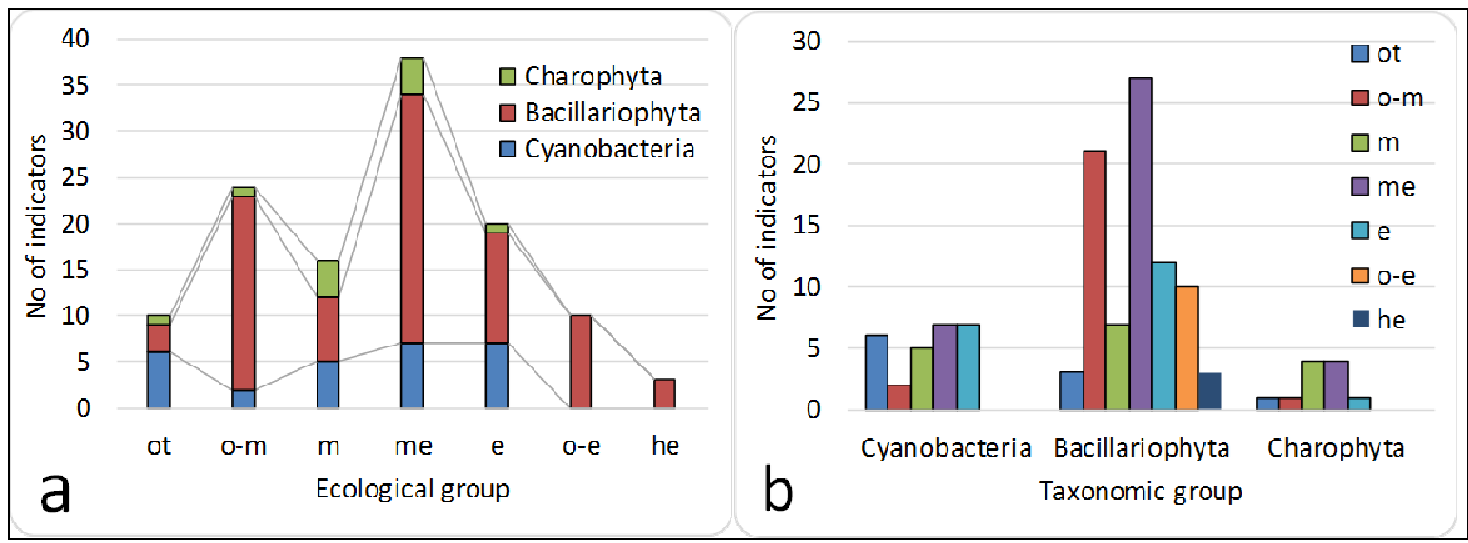

Figure 5: The number of indicator species in the three most representative divisions of algae in trophicity categories, arranged in increasing trophicity from left to right (a), and their ratio (b) in the divisions to which they belong.

Since the process of transformation of the $\mathrm{CP}$ ecosystem during the study period was described in detail earlier (Protasov et al., 2011, 2017; Protasov and Silaeva, 2014; Novosolova and Protasov, 2016), we only briefly note the main structural changes in phytoplankton in different periods of existence of technoecosystem.

In the initial (first) period of research (1998-2001), phytoplankton was characterized by a rich species composition (73-104 taxa), a high level of development, with dominance predominant of cyanobacteria and green algae. At the same time, biomass was dominated by green algae and diatoms. After introducing of Dreissena in the cooling pond, a decrease in the species richness of phytoplankton was observed (second period). Since 2006, representatives of Cryptophyta, Miozoa, Ochrophyta, Charophyta, and Cyanobacteria have progressively dropped out of the floristic list, and in September 2008, phytoplankton contained only nine taxa from three divisions. The restoration of species richness took place from 2009 to 2012 in the reverse order. In the second period, significant fluctuations in abundance and a decrease in biomass were observed. During the depression of the composition and abundance of phytoplankton (in 2008), quantitative indicators were formed mainly by diatoms. In the third period, a gradual increase in the abundance of phytoplankton was observed, the abundance was dominated by cyanobacteria and greens, in the biomass - green, diatoms, and cyanobacteria. The species richness ranged from 46 to 115 taxa.

The composition of species in phytoplankton and the richness of trophic indicator groups, and the cooling pond's trophic level have changed during the observation period. 


\section{Changes in the trophic state based on bioindication}

In 1998-2001, the level of water trophicity varied from "eupolitrophic" to "hypertrophic" (Fig. 6). The floristic spectrum of phytoplankton included indicators of all trophicity categories. Species-indicators of meso-eutrophic waters prevailed, the second and third places were among representatives of the categories oligo-mesotrophic and eutrophic waters (Figs. 7 and 8). This ratio was maintained for almost the entire duration of the research. It should be noted that the indicator species of these categories of trophicity reached a high level of development and were part of the dominant phytoplankton complexes (Tab. 1).

Table 1: Dynamics of species-indicators of trophic state (Tro) in the dominant complexes with the highest abundance of phytoplankton species in the CP KhNPP.

\begin{tabular}{|c|c|c|c|c|c|c|c|c|c|c|c|c|c|c|c|c|c|}
\hline Tro & Taxa & $\frac{\infty}{2}$ & $\frac{\infty}{\stackrel{\infty}{\sigma}}$ & $\frac{\infty}{2}$ & $\frac{\infty}{2}$ & $\frac{\infty}{2}$ & $\frac{\infty}{2}$ & $\frac{\infty}{2}$ & $\begin{array}{l}\frac{\infty}{2} \\
\stackrel{2}{\circ} \\
\stackrel{0}{0}\end{array}$ & $\frac{\infty}{2}$ & $\frac{\infty}{2}$ & $\frac{\infty}{2}$ & $\frac{\infty}{2}$ & $\frac{\infty}{2}$ & $\begin{array}{l}\frac{\infty}{2} \\
\stackrel{2}{\circ} \\
\stackrel{0}{0}\end{array}$ & $\frac{\infty}{2}$ & $\frac{\infty}{2}$ \\
\hline & \multicolumn{17}{|l|}{ Cyanobacteria } \\
\hline $\mathrm{m}$ & $\begin{array}{l}\text { Aphanizomenon } \\
\text { flosaquae Ralfs } \\
\text { ex Bornet and } \\
\text { Flahault }\end{array}$ & + & - & - & + & - & - & - & - & - & - & - & - & - & - & - & - \\
\hline me & $\begin{array}{l}\text { Aphanocapsa } \\
\text { incerta } \\
\text { (Lemmermann) } \\
\text { G. Cronberg } \\
\text { and Komárek }\end{array}$ & + & + & - & - & - & - & - & - & + & - & + & - & - & - & + & - \\
\hline me & $\begin{array}{l}\text { Aphanothece } \\
\text { stagnina } \\
\text { (Sprengel) A. } \\
\text { Braun }\end{array}$ & - & - & + & - & - & - & - & - & - & - & - & - & - & - & - & - \\
\hline $\mathrm{e}$ & $\begin{array}{l}\text { Microcystis } \\
\text { aeruginosa } \\
\text { (Kützing) } \\
\text { Kützing } \\
\end{array}$ & + & - & - & - & + & - & - & - & + & + & + & + & + & + & - & + \\
\hline me & $\begin{array}{l}\text { Oscillatoria } \\
\text { planctonica } \\
\text { Woloszynska }\end{array}$ & - & - & - & - & - & - & - & - & - & - & - & - & - & - & - & - \\
\hline me & $\begin{array}{l}\text { Snowella } \\
\text { lacustris } \\
\text { (Chodat) } \\
\text { Komárek and } \\
\text { Hindák }\end{array}$ & - & - & - & - & - & - & - & - & - & - & - & - & - & - & - & - \\
\hline & Bacillariophyta & & & & & & & & & & & & & & & & \\
\hline me & $\begin{array}{l}\text { Aulacoseira } \\
\text { granulata } \\
\text { (Ehrenberg) }\end{array}$ & - & - & - & - & + & - & + & + & - & - & + & + & - & + & + & + \\
\hline $\begin{array}{l}\mathrm{o}- \\
\mathrm{m}\end{array}$ & $\begin{array}{l}\text { Lindavia comta } \\
\text { (Kützing) T. } \\
\text { Nakov et al. }\end{array}$ & - & - & + & - & - & - & - & - & - & - & - & - & - & - & - & - \\
\hline $\mathrm{me}$ & $\begin{array}{l}\text { Melosira } \\
\text { varians C. } \\
\text { Agardh }\end{array}$ & - & - & - & - & + & + & - & - & - & - & - & - & - & - & - & - \\
\hline $\begin{array}{l}\mathrm{o}- \\
\mathrm{m}\end{array}$ & $\begin{array}{l}\text { Stephanodiscus } \\
\text { hantzschii } \\
\text { Grunow }\end{array}$ & + & - & - & - & - & - & + & - & - & - & + & - & - & - & - & - \\
\hline
\end{tabular}


As noted above, the response of phytoplankton to changes in the exploitation regime and the introduction of Dreissena was a decrease in its taxonomic richness. In the second period of research, the quantitative indicators of phytoplankton corresponded to trophicity categories from "oligotrophic" to "eutrophic", i.e., decreased by three categories. The number of indicators of trophicity has decreased significantly. Indicators of hypertrophic waters dropped out. Widely specialized indicators of oligo-mesotrophic waters were stably met. Representatives of other categories in different years of this period were either absent or noted in the list of species (Figs. 7 and 8). Most often, indicators of meso-eutrophic waters dominated in quantitative terms (Tab. 1).

In the third observation period, after a significant decrease in the abundance of the Dreissena polymorpha population occurred in the benthos and periphyton, an increase in trophicity to the "meso-eutrophic" - "eupolytrophic" level was observed (Fig. 6).

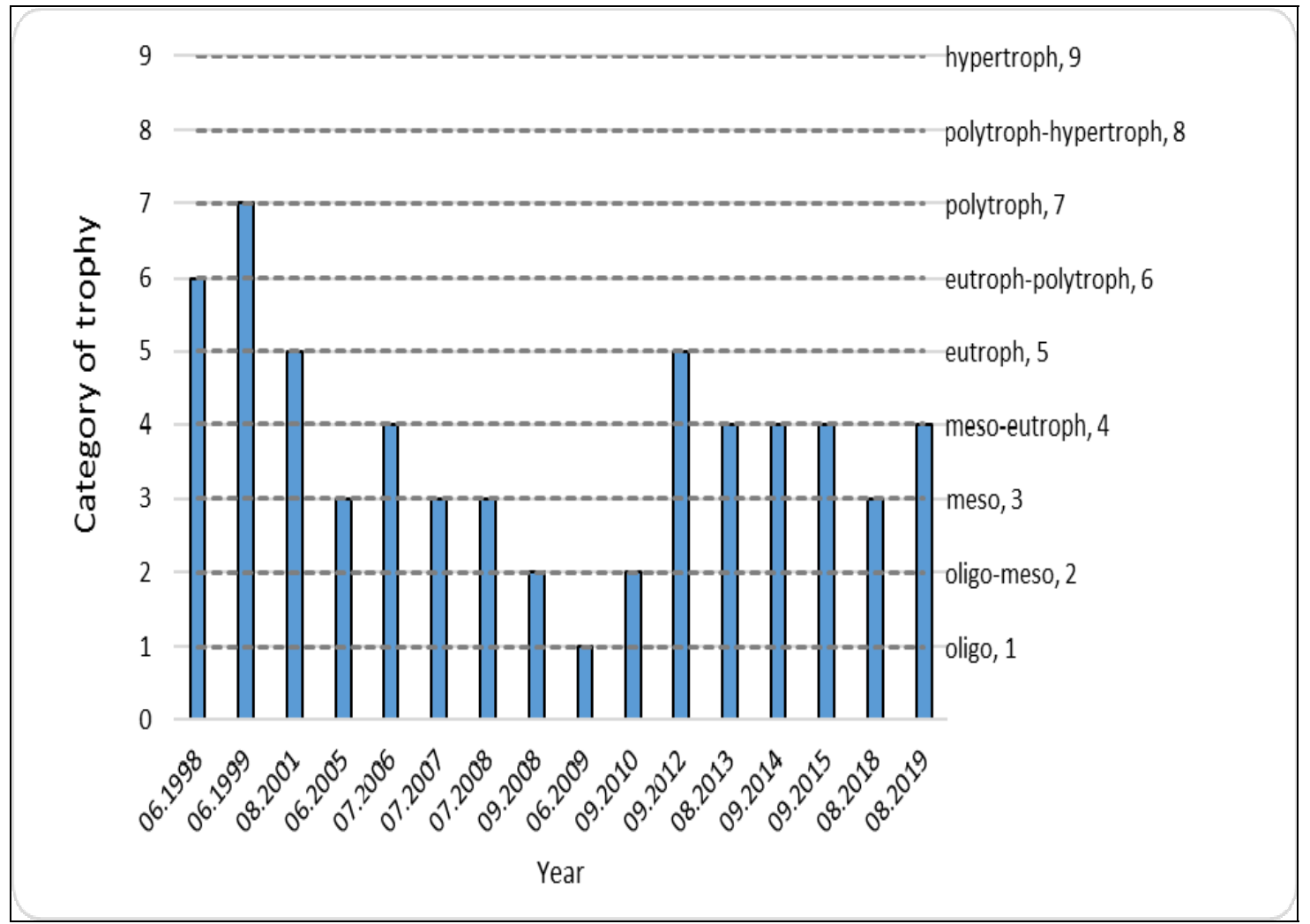

Figure 6: Long-term dynamics of trophicity categories of the CP KhNPP by indicators of the level of phytoplankton development (Oksiyuk et al., 1994).

In phytoplankton, the list of trophicity indicators expanded, and hypertrophs reappeared. The dominant observed assemblages, as well as at the initial stage of the research, included indicator species of oligo-mesotrophic, meso-eutrophic, and eutrophic waters. 


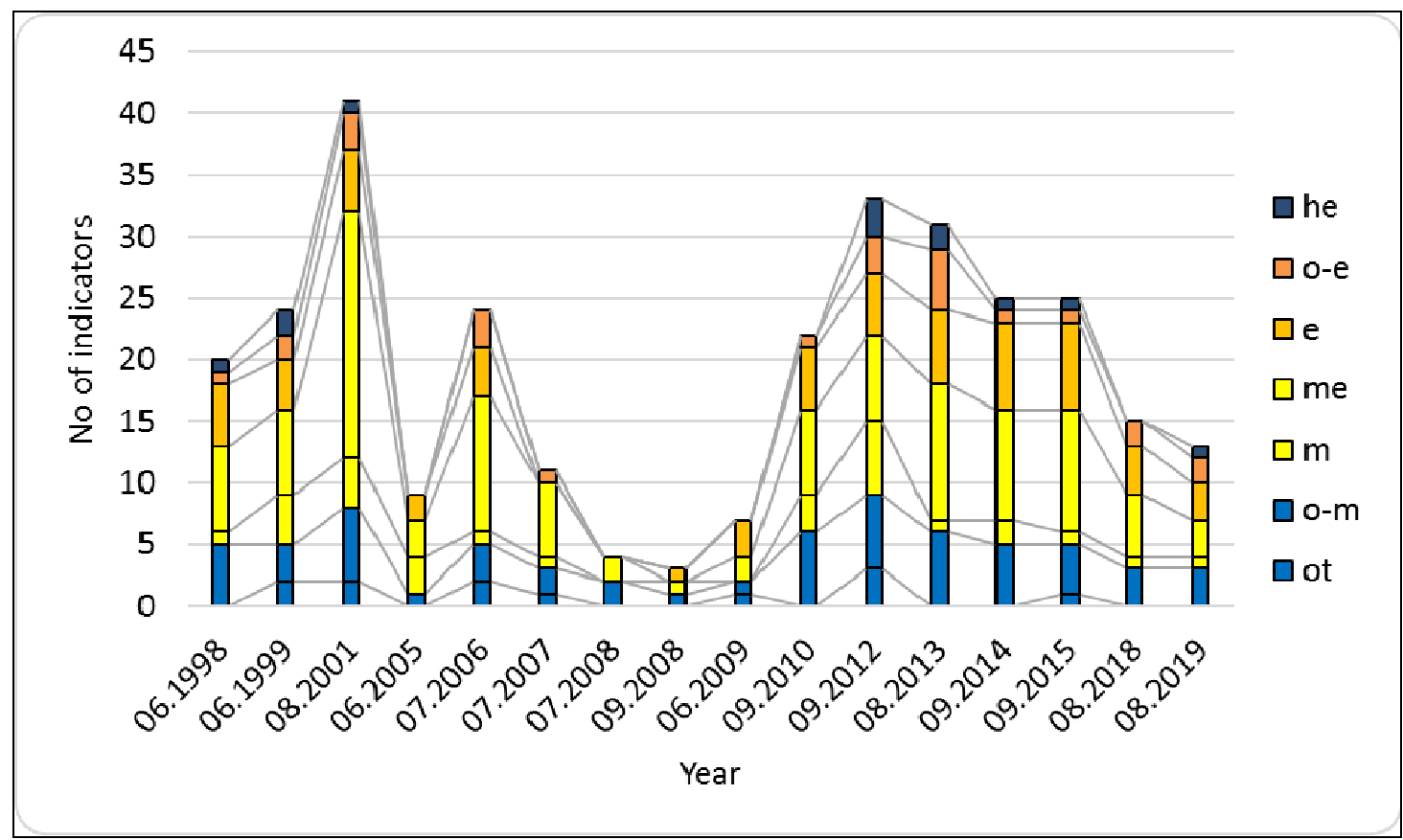

Figure 7: Long-term dynamics of taxonomic richness of trophic indicator species in phytoplankton of CP KhNPP. Groups of oligotrophic (blue) mesotrophic (yellow), eutrophic (orange) and hypertrophic indicators (black) are painted with the same color.

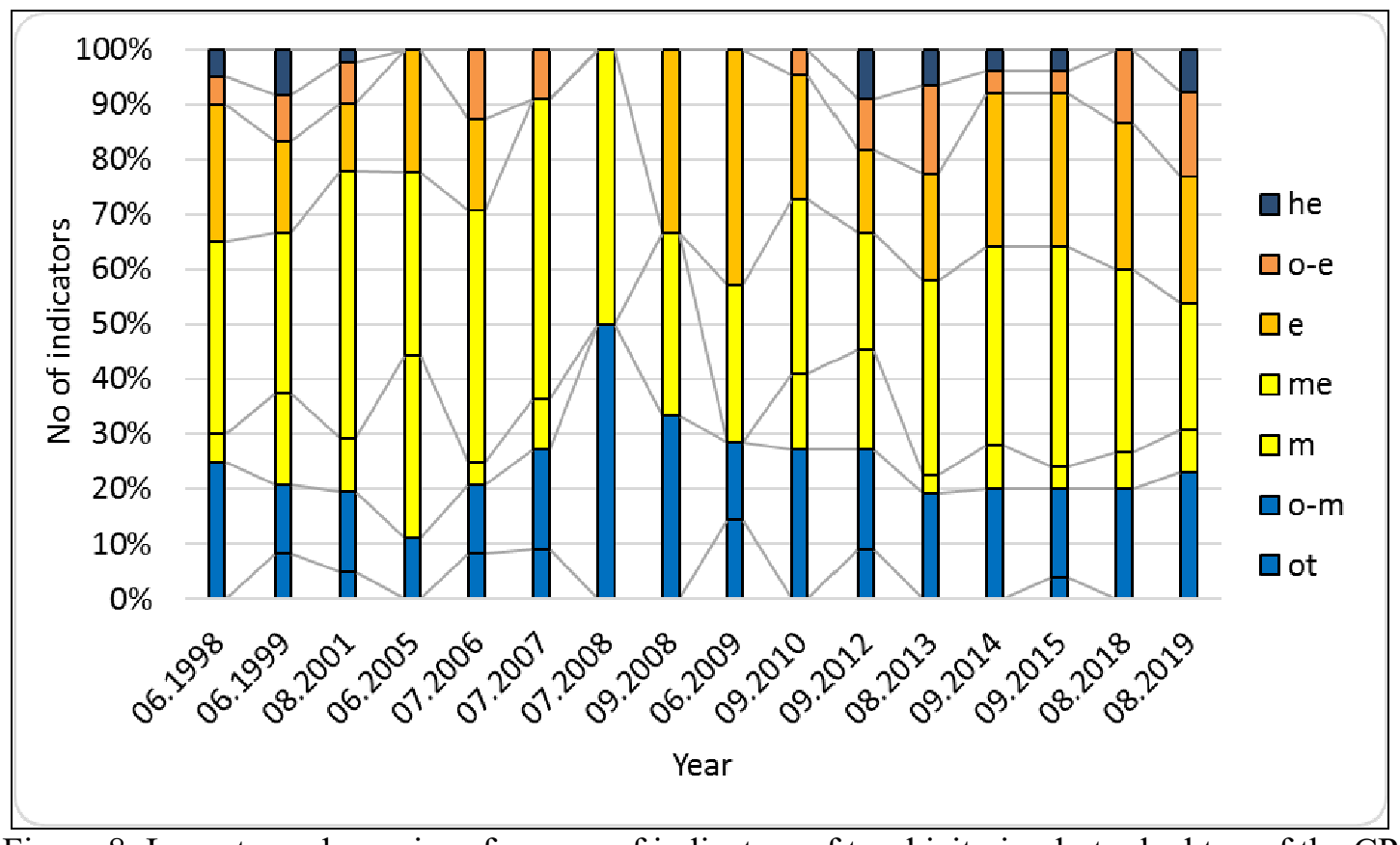

Figure 8: Long-term dynamics of groups of indicators of trophicity in phytoplankton of the $\mathrm{CP}$ KhNPP. Groups of oligotrophic (blue) mesotrophic (yellow), eutrophic (orange) and hypertrophic indicators (black) are painted with the same color. 
It should be noted that the grouping of indicator species, a kind of "sub-community"/quasi-community of indicators, is, apparently, not just a list formed by researchers for the convenience of environmental assessments, but a real coenotic grouping. This is indicated by the fact that the dynamics of the indicator of the diversity of indicator groups (Fig. 9) had certain tendencies of change. For example, in 1998, the grouping of indicators included five types of oligomesotrophs, one type of oligoeutrophs, one type of mesotrophs, seven types of mesoeutrophs, five species of eutrophs, one type of hypertrophs. In summer 2008, the structure was as follows: two types of oligomesotrophs and two types of mesoeutrophs. After the general depression of phytoplankton, the quasi-community of indicators gradually recovered during 2009-2012. This process in the ecosystem (we previously called it decontourization (Protasov and Silaeva, 2014) took a long time. Then the indicators of diversity went to average, as it was before contourization processes, after the introduction of Dreissena, the level is about two bits/ind. group.

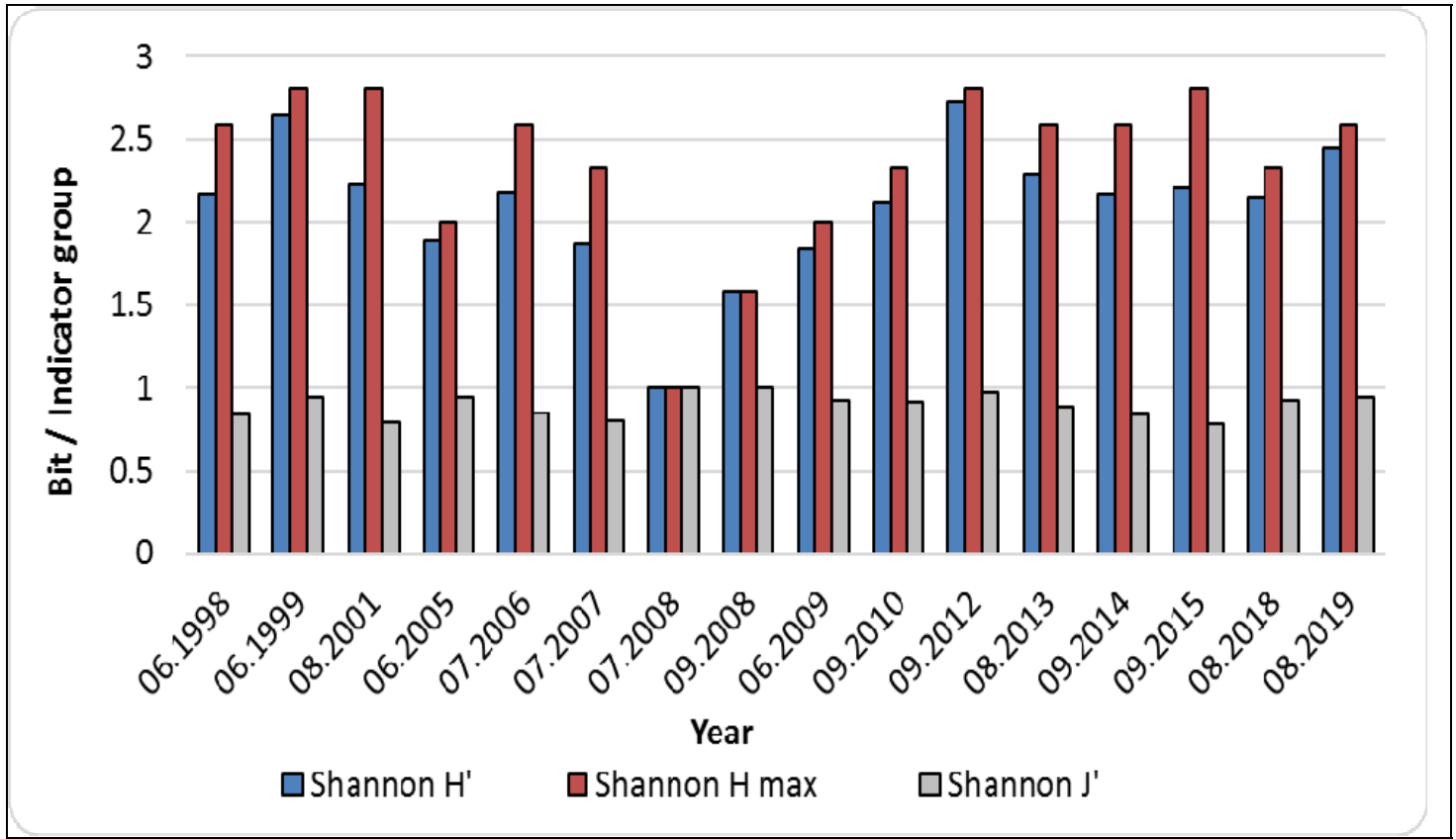

Figure 9: Dynamics of changes in the index of species diversity $\mathrm{H}$, maximum index of diversity $\mathrm{H}$ max and evenness $\mathrm{J}$ of the wealth of indicator groups in the "sub-community" of indicator types.

The indicator of diversity adopted by us varied both on the number of indicator groups and the saturation of their species. So, from 2008 to 2012, the number of indicator groups increased from two to seven (Fig. 10a). Although, in 2013, the number of indicator species on average per indicator group, decreased (from 5.2 in 2013 to 1.8 in 2019), due to the high uniformity the diversity was quite high (Fig. 10b). 


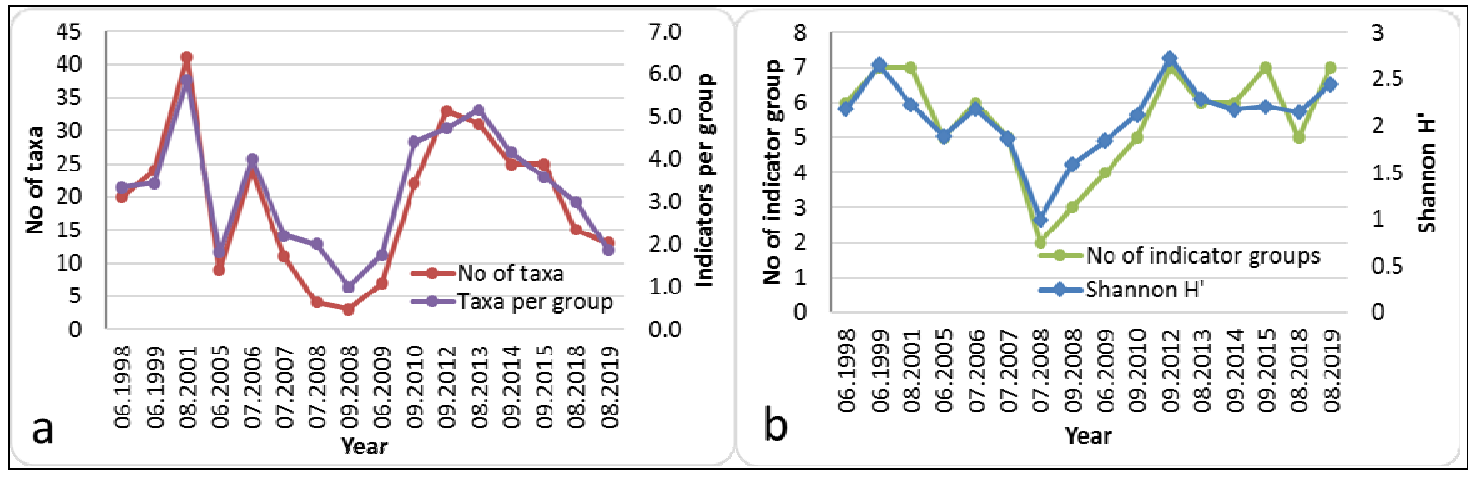

Figure 10: Dynamics of the number of indicator groups and species richness

(a) and saturation of groups with indicator species (b) during the study period.

The graphs in figure 10 show that the number of species per group of trophic indicators repeats the species richness (a). At the same time, the Shannon index repeats the number of groups of trophic indicators (b). Moreover, in the third period, both of these pairs are in antiphase, which suggests that both for the structural properties of the pond ecosystem and for trophicity indicators, the key moment (Gumpinger et al., 2008) of cardinal changes is a decrease in the species richness of phytoplankton.

Earlier, we noted (Protasov et al., 2019) a close relationship between the distribution patterns of Shannon indices and species richness in algal communities relative to the trophic level of the water body. At the same time, excessive emphasis on the indices of species diversity (Pore et al., 2020) distracts the researcher's attention from a really important issue trends in the trophicity of the reservoir, based on which important technical and administrative decisions are made. At the same time, the results of the current work reveal similar patterns in the dynamics of the species richness of algae and indicators of trophicity, presenting prospects for the development of new simple criteria (Dedić et al., 2020) for determining trends in change trophicity of a water body in a changing environment along with ecological modeling (Barinova, 2017), and which can be used for monitoring in future.

\section{CONCLUSIONS}

The KhNPP cooling pond's trophic status varied within wide limits during the entire study period on the background of an increase in the power plant's capacity. Reorganization of the ecosystem, benthos, and periphyton was observed, caused by invasion and mass development, and then partial elimination of the filter-feeding mollusk $D$. polymorpha. The range was very wide: between the first and seventh trophicity categories according to (Oksiyuk et al., 1994). In the process of these transformations, the composition and richness of trophic indicator species in phytoplankton changed. A kind of quasi-community of indicator species was formed and rebuilt. In the list of species throughout the study, the greatest richness was noted in the indicators of meso-eutrophic waters. Their representatives were most often part of the dominant phytoplankton complexes. At the same time, indicators of oligo-mesotrophic waters were constantly observed in the floristic spectrum. Hypertrophs were observed only at the first and third stages of research when the level of trophicity in terms of the abundance of algae was high (categories 4-7). In the long-term aspect, the dynamics of the taxonomic richness of the trophicity indicators coincided with the dynamics of the trophicity of the waters of the KhNPP. 
Thus, the use of phytoplankton biological indication methods along with traditional hydrobiological research methods increases the representativeness of assessing the state of aquatic ecosystems. Based on bioindication, it was possible to establish the nature of deep restructuring in the technoecosystem, which was associated with a change in the operating mode of the power plant and the introduction of invasive species of aquatic organisms.

\section{ACKNOWLEDGEMENTS}

This work was partly supported by National Academy of Sciences of Ukraine, project 141/0119U000325. This work was partly supported by Israeli Ministry of Aliya and Integration. 


\section{REFERENCES}

1. Arsan O. M., Davydov O. A. and Dyachenko, T. M., 2006 - Methods of hydrobiological studies of surface waters, Logos, Kyiv, Ukraine, 408. (in Ukrainian)

2. Bakanov A. I., 1997 - Using the characteristics of zoobenthos diversity for monitoring of the state of freshwater ecosystems, Monitoring of Biodiversity, Borok, 278-282. (in Russian)

3. Barinova S. S., Medvedeva L. A. and Anissimova O. V., 2006 - Diversity of algal indicators in environmental assessment, Tel Aviv, Pilies Studio, 458. (in Russian)

4. Barinova S.S., 2017 - Empirical model of the functioning of aquatic ecosystems, International Journal of Oceanography and Aquaculture, 1, 3, 1-9, 000113.

5. Barinova S., Bilous O. and Tsarenko P. M., 2019 - Algal indication of water bodies in Ukraine: methods and perspectives, Haifa University Publishing House, Haifa, Kiev, 367.

6. Beshkova M., Kalchev R. and Kalcheva H., 2014 - Phytoplankton in the Zhrebchevo Reservoir (Central Bulgaria) before and after invasion of Dreissena polymorpha (Mollusca: Bivalvia), Acta Zoologica Bulgarica, 66, 3, 399-409.

7. Beshkova M., Belkinova D. and Kalchev R., 2017 - Influence of Dreissena polymorpha (Pallas, 1771) (Mollusca: Bivalvia) on phytoplankton and physicochemical characteristics of Bulgarian Reservoirs, Acta Zoologica Bulgarica, Supplement, 9, 171-180.

8. Cuhel R. L. and Aguilar C., 2013 - Ecosystem transformations of the Laurentian Great Lake Michigan by nonindigenous biological invaders, Annual Review of Marine Science, 5, 289-320.

9. Dedić A., Gerhardt A., Kelly M. G., Stanić-Koštroman S., Šiljeg M., Kalamujić Stroil B., Kamberović J., Mateljak Z., Pešić V., Vučković I., Snigirova A., Bogatova Y., Barinova S., Radulović S., Cvijanović D., Lasić A., Škobić D., Sudar A., Mrđen D. and Herceg N., 2020 Innovative methods and approaches for WFD: ideas to fill knowledge gaps in science and policy, Water Solutions, 3, 30-42.

10. Guiry M. D. and Guiry M., 2019 - AlgaeBase. World-wide electronic publication, National University of Ireland, Galway, http://www.algaebase.org.

11. Gumpinger C. and Scheder C., 2008 - Decline of biodiversity as a result of various human impacts related to river regulation - exemplified by several small river catchments (Austria), Transylvanian Review of Systematical and Ecological Research, Sibiu, Romania, 6, 141-148.

12. Karatayev A., Burlakova L. and Padilla D., 1997 - The effects of Dreissena polymorpha (Pallas) invasion on aquatic communities in Eastern Europe, Journal of Shellfish Research, 16, 1, 187203

13. Novoselova T. N. and Protasov A. A., 2015 - Phytoplankton of cooling ponds of technoecosystems of nuclear and thermal power stations (a review), Hydrobiological Journal, 51, 3, 37-52.

14. Novoselova T. M. and Protasov O. O., 2016 - Features of phytoplankton of power plants technoecosystems (on the example of Khmelnitsky NPP), Botany and Mycology: Modern Horizons, Collection of Works, Kyiv, 344-367. (in Ukrainian)

15. Oksiyuk O. P., Zhdanova G. A., Gusynskaya S. L. and Golovko T. V., 1994 - Assessment of the state of water bodies in Ukraine by hydrobiological indicators, 1, Plankton, Hydrobiological Journal, 30, 3, 26-31. (in Russian).

16. Pore S., Ghosh S., Keshri J. P. and Barinova S. S., 2020 - Phytoplankton-based biomonitoring in assessing the pollution level of a lentic freshwater body in Hooghly District, West Bengal, India, Aquatic Bioresources and Environment, 3, 4, 50-62, http://journal.azniirkh.ru, www.azniirkh.ru, DOI: $10.47921 / 2619-1024$ 2020_3_4_50.

17. Protasov O. O., Semenchenko V. P. and Silaeva A. A., 2011 - Techno-ecosystem of the nuclear power plant. Hydrobiology, abiotic factors, ecological estimations, Kyiv, 234. (in Russian)

18. Protasov A. A. and Silaeva A. A., 2014 - Contour community of hydrobionts in technoecosystems of TPP and NPP, Kyiv, 274. (in Russian) 
19. Protasov A. A., Barinova S. S. and Novoselova T. N., 2017 - Characteristics of the ecological state of a cooling pond of a nuclear power station based on bioindication indices of phytoplankton, Hydrobiological Journal, 53, 4, 3-21, DOI: 10.1615/HydrobJ.v53.i4.10.

20. Protasov A. A., Silaeva A. A., Novoselova T. N., 2017 - Technoecosystem of NPP: 18 years of hydrobiological observations, Journal Siberian Federal University. Biology, 10, 4, 459-484, DOI: 10.17516/19971389-0045. (in Russian)

21. Protasov A., Barinova S., Novoselova T. and Sylaieva A., 2019 - The aquatic organisms diversity, community structure, and environmental conditions, Diversity, 11, 190-207, https://doi.org/10.3390/d11100190

22. Zdanowski B. and Protasov A. A., 1998 - Structura i funkcjonowanie podgrzanych jezior Koninskich - wnioski dla ochrony i zagospodarowania zbiornikow, Jeziora Koninskie - 40 lat badan stan aktualny oraz wnioski dla ochrony. Konin: Wojowodski Inspektorat Ochrony Srodowiska w Koninie, Poland, 54-58 (in Polish). 